\title{
Emerging new climate extremes over Europe
}

Article

Published Version

Creative Commons: Attribution 4.0 (CC-BY)

Open Access

Osso, A. ORCID: https://orcid.org/0000-0001-5653-4886, Allan, R. P. ORCID: https://orcid.org/0000-0003-0264-9447, Hawkins, E. ORCID: https://orcid.org/0000-0001-9477-3677, Shaffrey, L. and Maraun, D. (2022) Emerging new climate extremes over Europe. Climate Dynamics, 58. pp. 487-501. ISSN 0930-7575 doi: https://doi.org/10.1007/s00382-02105917-3 Available at https://centaur.reading.ac.uk/99966/

It is advisable to refer to the publisher's version if you intend to cite from the work. See Guidance on citing.

To link to this article DOI: http://dx.doi.org/10.1007/s00382-021-05917-3

Publisher: Springer

All outputs in CentAUR are protected by Intellectual Property Rights law, including copyright law. Copyright and IPR is retained by the creators or other copyright holders. Terms and conditions for use of this material are defined in the End User Agreement.

\section{www.reading.ac.uk/centaur}

\section{CentAUR}


Central Archive at the University of Reading

Reading's research outputs online 


\title{
Emerging new climate extremes over Europe
}

\author{
Albert Ossón ${ }^{1,2}\left(\mathbb{D} \cdot\right.$ Richard P. Allan ${ }^{2,3} \cdot$ Ed Hawkins $^{2,4} \cdot$ Len Shaffrey $^{2,4} \cdot$ Douglas Maraun $^{1}$
}

Received: 23 October 2020 / Accepted: 1 August 2021

(c) The Author(s) 2021

\begin{abstract}
Human society and natural systems are intrinsically adapted to the local climate mean and variability. Therefore, changes relative to the local expected variability are highly relevant for assessing impact and planning for adaptation as the climate changes. We analyse the emerging climate signal relative to the diagnosed internal variability (signal-to-noise ratio, S/N) of a set of recently published climate indices over Europe. We calculate the signal-to-noise ratio with respect to a recent baseline (1951-1983) which relates to recent societal experience. In this framework, we find that during the 2000-2016 period, many areas of Europe already experienced significant changes in climate extremes, even when compared to this recent period which is within living memory. In particular, the $\mathrm{S} / \mathrm{N}$ of extreme temperatures is larger than 1 and 2 over $34 \%$ and $4 \%$ of Europe, respectively. We also find that about $15 \%$ of Europe is experiencing more intense winter precipitation events, while in summer, $7 \%$ of Europe is experiencing stronger drought-inducing conditions.
\end{abstract}

\section{Introduction}

Climate change is a global phenomenon, but its impacts differ regionally and seasonally. Societal and natural systems are intrinsically adapted to the local climate in which they are embedded, its mean value and the typical variability range. Exposed to the same mean change, systems adapted to larger variability are usually more resilient than systems that have evolved in more stable climates. For example, for the same temperature increase, tropical ecosystems are generally more vulnerable than extratropical ones, which are adapted to the larger variability of the midlatitudes (Dillon et al. 2010; Mahlstein et al. 2011; Frame et al. 2017; Harrington et al. 2016). Therefore, from an impact point of view, it may not be the absolute change but the change relative to the background variability that is especially relevant (Deutsch et al. 2008; Beaumont et al. 2011). A way

Albert Ossó

albert.osso-castillon@uni-graz.at

1 Wegener Center for Climate and Global Change, University of Graz, Graz, Austria

2 Department of Meteorology, University of Reading, Reading, UK

3 National Centre for Earth Observation, University of Reading, Reading, UK

4 National Centre for Atmospheric Science, University of Reading, Reading, UK to quantify this relation is by analysing the signal-to-noise ratio $(\mathrm{S} / \mathrm{N})$, where the signal $(\mathrm{S})$ is a measure of the mean change of some climate metric respect to a baseline ("the past experience"), and the noise $(\mathrm{N})$ is a representative measure of the variability. The concept of $\mathrm{S} / \mathrm{N}$ is closely related to the concept of Time of Emergence (ToE) of climate signals (e.g., Christensen et al. 2007; Giorgi and Bi 2009; Hawkins and Sutton 2012; Maraun 2013). ToE is the year in which a climate signal emerges from the background variability and is estimated by determining the date on which the $\mathrm{S} / \mathrm{N}$ ratio permanently crosses a certain threshold. A different perspective is to focus on the $\mathrm{S} / \mathrm{N}$ value itself on a particular date and try to answer the question: "How familiar or unfamiliar is the current climate in a particular region with respect to the past experience?". In this context, Frame et al. (2017) describe how the climate changes with respect to past experience using the terms' unusual' ( $\mathrm{S} / \mathrm{N}>1$ ), 'unfamiliar' $(\mathrm{S} / \mathrm{N}>2)$ and 'unknown' $(\mathrm{S} / \mathrm{N}>3)$. Using these categories, Hawkins et al. (2020) calculate the S/N of changes in temperature and precipitation observations and show that many regions are already experiencing a climate that would be unknown by late nineteenth century standards. Over Europe, changes in temperature and temperature extremes have been detected and attributed partially to anthropogenic influences both in models (e.g., King et al. 2015) and observations (Mahlstein et al. 2012). Zhang et al. (2007) analyses changes in precipitation averaged over latitudinal bands and found that a positive change over northern hemisphere high 
latitudes is attributable to anthropogenic forcing. Maraun (2013) analyses a multi-model ensemble of regional climate projections and found that in the next few decades, positive winter trends in mean and heavy precipitation will emerge in northern Europe and trends in mean precipitation will emerge in summer in southwestern and southeastern Europe. Most of these studies investigate if the trends can be attributed to anthropogenic greenhouse gas forcing, and therefore they use a pre-industrial baseline period. However, due to the lack of high-resolution and homogeneous observational data on pre-industrial times, these studies are based on model data or limit the analysis to a few climate metrics with a relatively coarse spatial resolution. To circumvent this issue, here we analyse how impact-related climate indices have changed in Europe with respect to a more recent baseline (1951-1983). Using a more recent baseline allows us to analyse more climate metrics that are derived from highquality, high-resolution observational data, but the reported changes cannot be directly attributed to anthropogenic forcing. However, we argue that these results are relevant for adaptation planning since they relate with recent societal experience, including personal (memory) or practical/technical (most of the European infrastructure has been built after 1950 , partially because of the destruction associated with World War II).

\section{Methods}

As in Hawkins et al. (2020), we estimate the $\mathrm{S} / \mathrm{N}$ by regressing seasonal local climate variations onto seasonal global mean surface temperature (GMST) change, that is,

$L(t)=\alpha G(t)+b$,

where $\mathrm{L}(\mathrm{t})$ is the observed local anomaly of some climate metric, $\mathrm{G}(\mathrm{t})$ is a smoothed version of GMSTs for the period 1951-2016, and $\alpha$ and $\beta$ are the parameters of the linear model. We limit the analysis to the period 1951-2016 since this is the period available for the impact-related indices (see description of the indices below). All the anomalies are calculated with respect to the 1951-1983 baseline period except for SPEI3 and ETO (see Table 1), which we use the period 1980-1997 due to data availability.

$\mathrm{G}(\mathrm{t})$ is calculated by using monthly-mean near-surface temperature anomalies from the interpolated (gap-filled) HadCRUT4 dataset (Cowtan and Way 2014) smoothed with a 15 -year running mean. The conclusions are insensitive to whether the smoothing parameter is slightly larger or smaller. The 'signal' of global temperature change ( $\Delta$ GMST) is defined as the value of the smoothed GMST in 2016 minus smoothed GMST in 1951 ( $\Delta$ GMST $\sim 0.62 \mathrm{~K})$, the component of local climate change explained by GMST (S) is $\alpha G$, and the 'noise' $(\mathrm{N})$ is defined as the standard deviation of the residuals $(L-\alpha G)$. This framework assumes that $\alpha G$ is a good representation of the forced component of the local change. This assumption has been shown to be quite accurate in several studies. For example, Sutton et al. (2015) show that GMST changes explain a large fraction of the local climate change temperature signal, while Fisher and Knutti (2014) shows that a similar linear regression framework provides robust estimates of the local $\mathrm{S} / \mathrm{N}$ future extremes of temperature and precipitation. The statistical significance of the linear regression coefficients is estimated using a two-tailed Student's t-test with adjusted p-values to avoid the overestimation associated with multiple testing (Wilks 2006). The p-value adjustment is performed following the false discovery rate test suggested by Wilks (2006). We calculate the percentage of area with a $\mathrm{S} / \mathrm{N}$ over a certain threshold by adding the surface area of the grid points with a statistically significant $\mathrm{S} / \mathrm{N}$ above the threshold divided by the total area covered by the data.

To illustrate this approach, Fig. 1 shows summer and winter global (Fig. 1a, b) and local (Fig. 1c, D) mean surface temperature anomalies for the 1951-2016 period used in the manuscript. The local temperature anomalies $\left(\mathrm{L}_{\mathrm{R}}\right)$ are from a single ERA5 grid cell $\left(0.25^{\circ} \times 0.25^{\circ}\right)$ containing the city of Reading (UK). The gridpoint has been taken for illustration proposes and does not correspond to the city temperatures but to that of the much larger grid cell, which covers about $480 \mathrm{Km}^{2}$. A 15 -year running mean of the time series is also shown. The global (GMST) and local $\left(\mathrm{L}_{R}\right)$ surface temperature anomalies show a similar temporal evolution. Their smooth versions have a temporal correlation of about 0.98 , showing that the fingerprint of GMST is clearly apparent at the local scale, although with larger noise. We regress $L_{R}$ onto the smooth GMST and obtain a regression coefficient $\alpha=(2.21 \pm 0.62) \mathrm{K}$ for winter and $\alpha=(2.36 \pm 0.43)$ for summer. The signal of $L_{R}$ is given by $\alpha \mathrm{G}_{2016}=(1.41 \pm 0.40) \mathrm{K}$ for winter and $(1.44 \pm 0.24) \mathrm{K}$ for summer. The noise is calculated as the standard deviation of the residuals $\left(L_{R}-\alpha G\right)$, and it is $1.18 \mathrm{~K}$ and $0.78 \mathrm{~K}$ for winter and summer, respectively. The $\mathrm{S} / \mathrm{N}$ ratio of $\mathrm{L}_{\mathrm{R}}$ is $(1.12 \pm 0.31)$ for winter and $(1.8 \pm 0.30)$ for summer.

\section{Data}

We estimate the $\mathrm{S} / \mathrm{N}$ for a set of impact-related indices that describe some of the major hazards affecting Europe: extremely high temperatures, flooding, and drought. The indices are a subset of a new gridded dataset developed in the framework of the ERA4CS INDECIS project (European Union Grant 690462). The indices are available at a $0.25^{\circ}$ resolution for the whole of Europe and consist of 125 climate indices spanning different periods based on 
Table 1 Definitions of the indices used in this study. The abbreviations and definitions follow Domínguez-Castro et al. (2020)

\begin{tabular}{|c|c|c|c|c|c|}
\hline Index code & Index name & Description and [units] & Data provider & Time period analysed & Reference \\
\hline Rx1d & $\begin{array}{l}\text { Maximum 1-day precipi- } \\
\text { tation }\end{array}$ & $\begin{array}{l}\text { Highest precipitation } \\
\text { amount in 1-day period } \\
{[\mathrm{mm} / \mathrm{month}]}\end{array}$ & $\begin{array}{l}\text { Daily precipitation from } \\
\text { EOBS }\end{array}$ & 1950-2017 & Klein Tank et al. (2009) \\
\hline $\mathrm{Rx} 5 \mathrm{~d}$ & $\begin{array}{l}\text { Maximum consecutive } \\
\text { 5-day precipitation }\end{array}$ & $\begin{array}{l}\text { Highest precipitation } \\
\text { amount in 5-day period } \\
{[\mathrm{mm} / \mathrm{month}]}\end{array}$ & $\begin{array}{l}\text { Daily precipitation from } \\
\text { EOBS }\end{array}$ & 1950-2017 & Klein Tank et al. (2009) \\
\hline R95tot & $\mathrm{R} 95 \mathrm{t}$ & $\begin{array}{l}\text { Precipitation due to very } \\
\text { wet days }(>95 \text { th per- } \\
\text { centile) divided by total } \\
\text { precipitation [\%] }\end{array}$ & $\begin{array}{l}\text { Daily precipitation from } \\
\text { EOBS }\end{array}$ & $1950-2017^{\mathrm{a}}$ & Klein Tank et al. (2009) \\
\hline LWP & Longest wet period & $\begin{array}{l}\text { Maximum length of } \\
\text { consecutive wet days } \\
(\mathrm{RR} \geq 1) \text { [days/month] }\end{array}$ & $\begin{array}{l}\text { Daily precipitation from } \\
\text { EOBS }\end{array}$ & 1950-2017 & Klein Tank et al. (2009) \\
\hline LDP & Longest dry period & $\begin{array}{l}\text { Maximum length of } \\
\text { consecutive dry days } \\
(\mathrm{RR}<1) \text { [days/month] }\end{array}$ & $\begin{array}{l}\text { Daily precipitation from } \\
\text { EOBS }\end{array}$ & 1950-2017 & McCabe et al. (2010) \\
\hline SPEI3 & SPEI3 & $\begin{array}{l}\text { Standardised precipita- } \\
\text { tion-evapotranspiration } \\
\text { index calculated at } \\
\text { 3-month time scale } \\
\text { [Standardised units] }\end{array}$ & ERA5 & $1979-2017^{\mathrm{a}}$ & $\begin{array}{l}\text { Vicente-Serrano et al. } \\
2010\end{array}$ \\
\hline SPI3 & SPI3 & $\begin{array}{l}\text { Standardised precipita- } \\
\text { tion index calculated at } \\
\text { 3-month [Standardised } \\
\text { units] }\end{array}$ & ERA5 & $1979-2017^{\mathrm{b}}$ & McKee et al. (1993) \\
\hline ETO & $\begin{array}{l}\text { Reference Evapotranspi- } \\
\text { ration }\end{array}$ & $\begin{array}{l}\text { If data available using } \\
\text { Fao-56 Penman-Mon- } \\
\text { teith, if not using the } \\
\text { Hargreaves \& Samani } \\
\text { method. [mm/month] }\end{array}$ & ERA5 & $1979-2017^{\mathrm{b}}$ & Chiew et al. (1995) \\
\hline WD & Warm days & $\begin{array}{l}\text { Total numbers of days } \\
\text { with TX higher than the } \\
\text { 90th percentile [days/ } \\
\text { month] }\end{array}$ & $\begin{array}{l}\text { Daily temperature from } \\
\text { EOBS }\end{array}$ & $1950-2017^{\mathrm{a}}$ & Klein Tank et al. (2009) \\
\hline WN & Warms nights & $\begin{array}{l}\text { Total numbers of days } \\
\text { with TN higher than the } \\
\text { 90th percentile [days/ } \\
\text { month] }\end{array}$ & $\begin{array}{l}\text { Daily temperature from } \\
\text { EOBS }\end{array}$ & $1950-2017^{\mathrm{a}}$ & Klein Tank et al. (2009) \\
\hline D32 & $\begin{array}{l}\text { Temperature sums above } \\
32^{\circ} \mathrm{C} \text { (duration) }\end{array}$ & $\begin{array}{l}\text { Number of days with } \\
\mathrm{TX} \geq 32^{\circ} \mathrm{C} \text { [days/ } \\
\text { month] }\end{array}$ & $\begin{array}{l}\text { Daily temperature from } \\
\text { EOBS }\end{array}$ & 1950-2017 & Klein Tank et al. (2009) \\
\hline WSD & Warm spell duration & $\begin{array}{l}\text { Count of days with at } \\
\text { least } 6 \text { consecutive days } \\
\text { when TX }>90 \text { th percen- } \\
\text { tile [days/month] }\end{array}$ & $\begin{array}{l}\text { Daily temperature from } \\
\text { EOBS }\end{array}$ & $1950-2017^{\mathrm{a}}$ & Klein Tank et al. (2009) \\
\hline
\end{tabular}

$R R$ daily precipitation, $T N$ minimum daily temperature, $T X$ maximum daily temperature

${ }^{a}$ Percentiles are calculated using all the years available

${ }^{\mathrm{b}} 1980-1997$ is used as base line period

data availability, but mainly 1950-2017 and 1979-2017 (Domínguez-Castro et al. 2020). The indices are calculated with gridded daily surface air temperature, rainfall and sea level pressure data from the European Climate Assessment \& Dataset (ECA\&D) E-OBS version v17.0e (https://www. ecad.eu/download/ensembles/ensembles.php) (Cornes et al. 2018). E- ${ }^{3}$ available at a 0.1 spatial resolution for the
1950-2017 period. The rest of the required climate variables are obtained from the ERA5 reanalysis at $0.25^{\circ}$ resolution and spanning 1979-2017 (https://www.ecmwf.int/en/forec asts/datasets/reanalysis-datasets/era5).

The indices are selected to represent some of Europe's major hazards while being directly derived from temperature and precipitation data to ensure our methodology is applicable. 
A

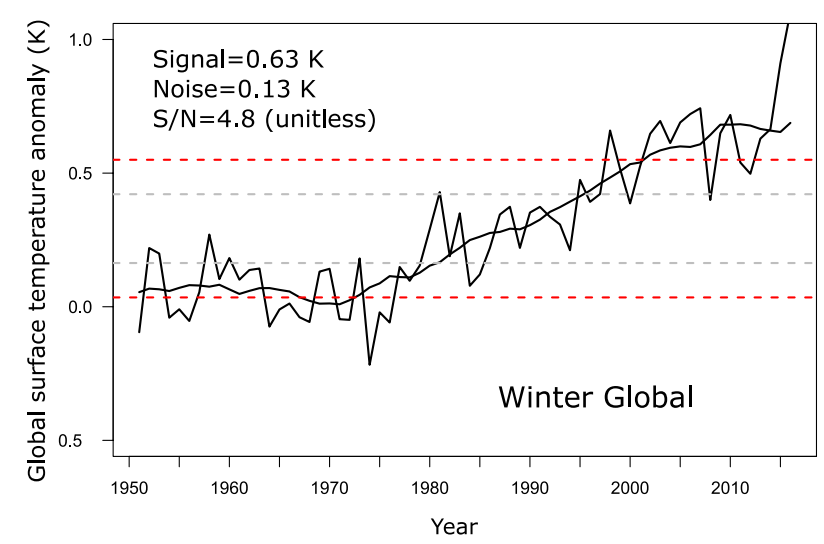

C

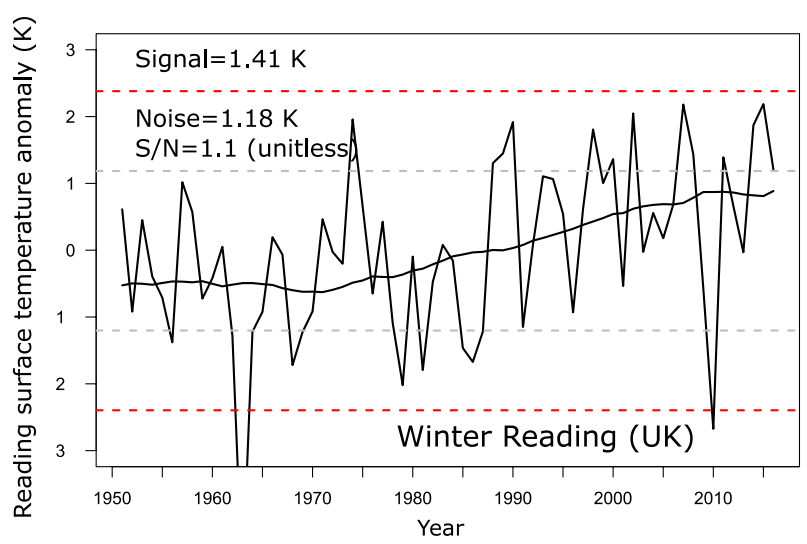

Fig. 1 Emergence of seasonal global and local surface temperature change from 1951 to 2016. A GMST (black), smoothed with a 15-year lowess filter (black). B As in (A) but for summer. C Seasonal temperature anomaly of a single grid point over Reading (UK) and

An exception is for the indices ETO and SPEI3, which derivation require extra information, and therefore the results regarding these two indices should be interpreted with caution. The indices used in this study are described in Table 1 . We tested the sensitivity of our results to the use of the E-OBS version $\mathrm{v} 21.0 \mathrm{e}$ by calculating the $\mathrm{S} / \mathrm{N}$ of temperature and total precipitation with this later E-OBS version. For temperature and precipitation, the $\mathrm{S} / \mathrm{N}$ derived from both versions are virtually identical for the overlapping period and regions (see Figure S1 and S2). Since most of the indices used in this study are derived from temperature and precipitation data from the E-OBS dataset (see Table 1), we do not expect any significant
B

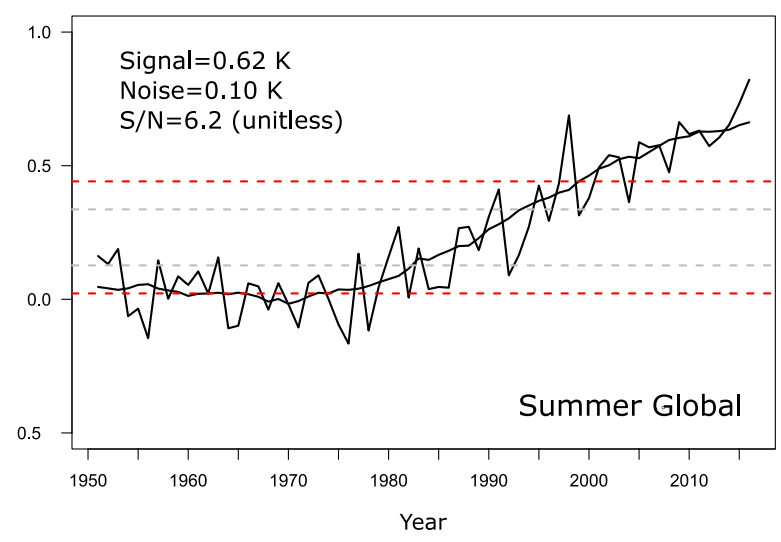

D

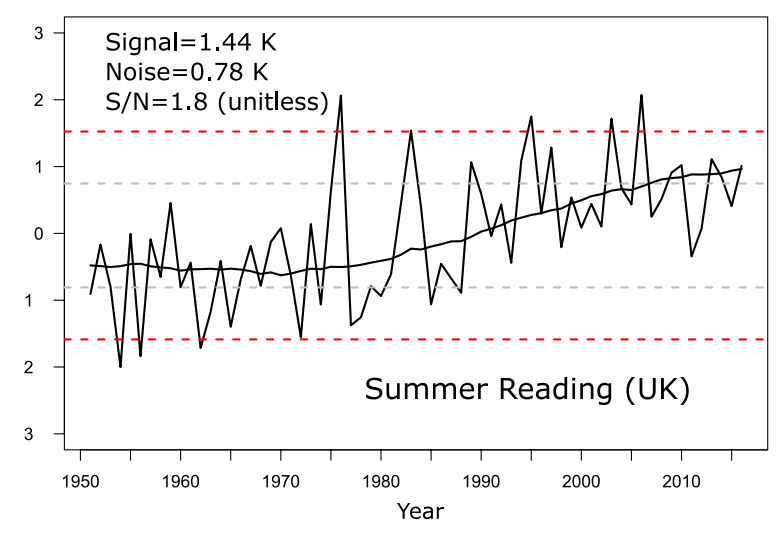

scaled smoothed GMST $(\alpha G(t))$. D as in $(\mathbf{C})$ but for summer. The dashed lines indicate 1 (grey) and 2 (red) standard deviations of the noise

change of our results to a future update of the indices database to the latest E-OBS versions.

\section{Results}

\section{1 $\mathrm{S} / \mathrm{N}$ of temperature-based indices}

\subsubsection{Seasonal mean temperatures}

Figure 2 shows the surface temperature (Ts) signal, noise and $\mathrm{S} / \mathrm{N}$ over Europe for different seasonal means. In winter (December, January, February: DJF), the spatial pattern 
of the signal and noise is characterised by a gradient from the south-west (SW) to north-east (NE) with the largest values over Belarus, western Russia and Scandinavia (Fig. 2a, b). The winter Ts signal is above $1{ }^{\circ} \mathrm{C}$ over all of Europe and up to $3{ }^{\circ} \mathrm{C}$ in Scandinavia and NE Europe. Interestingly, some regional features depart from the main pattern; in particular, large signals are also observed in the southern Alpine region and southern Italy, where the signals are above $3.5{ }^{\circ} \mathrm{C}$. The $\mathrm{S} / \mathrm{N}$ is larger than 1 over $26 \%$ of Europe (Fig. 2c), indicating that a substantial portion of Europe is experiencing unusually warm winter temperatures compared with the 1951-1983 period.

During springtime (March, April, May: MAM), the spatial pattern of the signal and the noise resembles that of winter (Fig. 2d, e). The magnitude of the signal is similar to winter, but the noise is about half of the size over central and northern Europe. The smaller noise increases the magnitude of $\mathrm{S} / \mathrm{N}$ over these areas (Fig. 2f). Overall, the $\mathrm{S} / \mathrm{N}$ of spring temperatures is larger than 1 and 2 over $82 \%$ and $3 \%$ of Europe, respectively.

In summer (June, July, August: JJA), the largest signals are observed over southern Europe (about $1.5^{\circ} \mathrm{C}$ ), with some areas of southern France, Italy and Spain exhibiting values larger than $2{ }^{\circ} \mathrm{C}$ (Fig. $2 \mathrm{~g}$ ). In contrast, the signal is smaller over Scandinavia and the UK (about $1^{\circ} \mathrm{C}$ ). The spatial pattern of the noise is remarkably homogeneous, and the values are the smallest of the year (Fig. 2d, e). The $\mathrm{S} / \mathrm{N}$ is larger than 1 over most continental Europe and larger than 2 over large patches of southern Europe and Iberia (Fig. 2f). In contrast, the signal has still not "emerged" $(\mathrm{S} / \mathrm{N}<1)$ in Scandinavia. Overall, the $\mathrm{S} / \mathrm{N}$ of summer temperatures is larger than 1 and 2 over $50 \%$ and $19 \%$ of Europe, respectively.

Finally, during autumn (September, October, November: SON), the signal is the smallest of the year and does not have a distinctive spatial pattern (Fig. 2j). The noise is larger than in summer, with the largest values over Scandinavia and NE Europe (Fig. 2k). The S/N appears to be dominated by the pattern of the noise, showing $\mathrm{S} / \mathrm{N}$ values above one over the western half of Europe and generally $\mathrm{S} / \mathrm{N}<1$ over NE Europe and Scandinavia (Fig. 21). Overall, the S/N of autumn temperatures is larger than 1 over $45 \%$ of Europe.

\subsubsection{Extreme temperature indices}

Heatwaves are a natural phenomenon often associated with persistent anticyclonic circulation anomalies (e.g., Trenberth and Fasullo 2012). However, heatwaves are becoming more intense and occurring more frequently due to anthropogenic global warming (e.g., Meehl and Tebaldi 2004; Perkins et al. 2012). Heatwaves are among the most dangerous of natural hazards. From 1998 to 2017, it is estimated more than 166,000 people died due to heatwaves associated heat stress ( https://www.who.int/health-topics/heatwaves), including more than 70,000 who died during the 2003 heatwave in Europe (Robine et al. 2008). Here, we analyse the $\mathrm{S} / \mathrm{N}$ of the following extreme temperatures climate indices described in Table 1: warm days (WD), warm nights (WN), very warm days (VWD), warm spell duration (WSD) and the number of days with maximum Ts $>32{ }^{\circ} \mathrm{C}$ (D32). These indices are related to the probability of heatwave occurrence and with the impact of heat on public health. We focus our attention on the summer season (JJA) since it is the season where heat impacts are more relevant.

The S/N of WD is above 1 in most of Europe except over Scandinavia and the UK (Fig. 3a). S/N values above 2 are observed across southern Europe, especially over the Iberian Peninsula, covering about $9 \%$ of European territory.

Understanding the changes in WN is very important for public health planning since humans need cooler night temperatures to recover. High night temperatures have a substantial contribution to the final death toll of a heatwave (Trigo et al. 2005). The S/N of WN (Fig. 3b) is generally larger than for WD, and its distribution is less homogenous. This asymmetry between daytime and nocturnal temperature trends has been observed in several studies and has been attributed primarily to an increase in cloud cover (e.g., Henderson-Sellers 1992; Dessens and Bücher 1995; Kaas and Frich 1995; Dai et al. 1999). The highest WN S/N values are found in southern Spain, Italy, the southern Alpine region and eastern Europe. Overall, the $\mathrm{S} / \mathrm{N}$ of $\mathrm{WN}$ is larger than 1 over $51 \%$ and larger than 2 and 3 over $20 \%$ and $3 \%$ of Europe, respectively.

The S/N of VWD is smaller than for WD. It exceeds 1 over central Europe and the Iberian Peninsula, covering about $30 \%$ of European territory (Fig. 3c).

By construction, the above temperature-related indices describe changes relative to the local climatology. Therefore, the spatial differences in their $\mathrm{S} / \mathrm{N}$ can be interpreted as a geographically differentiated response to forcing. Overall, the results suggest that the areas more exposed to Atlantic air advection such as NW Europe, Scandinavia and the UK have smaller $\mathrm{S} / \mathrm{N}$ values. This might be explained by the fact that air temperature change due to global warming is smaller over the oceans than over land (e.g., Sutton et al. 2007), so the transport of relatively cool marine air tempers the pace of the warming in comparison to more continental areas.

Figure 3d show the S/N of D32. D32 is based on a fixed threshold and can be directly related to health concerns. The $\mathrm{S} / \mathrm{N}$ of D32 is above 1 over large areas of continental Europe except over the mountainous areas of the Alps, the Pyrenees and the Sierra Nevada, where the higher altitudes maintain lower maximum temperatures, and over the NW coast of France, Scandinavia and the UK. Over the Iberian Peninsula, the $\mathrm{S} / \mathrm{N}$ values are larger, above 2 in central Spain and low-level locations such as the Ebro Depression. Overall, 


\section{Surface temperatures}
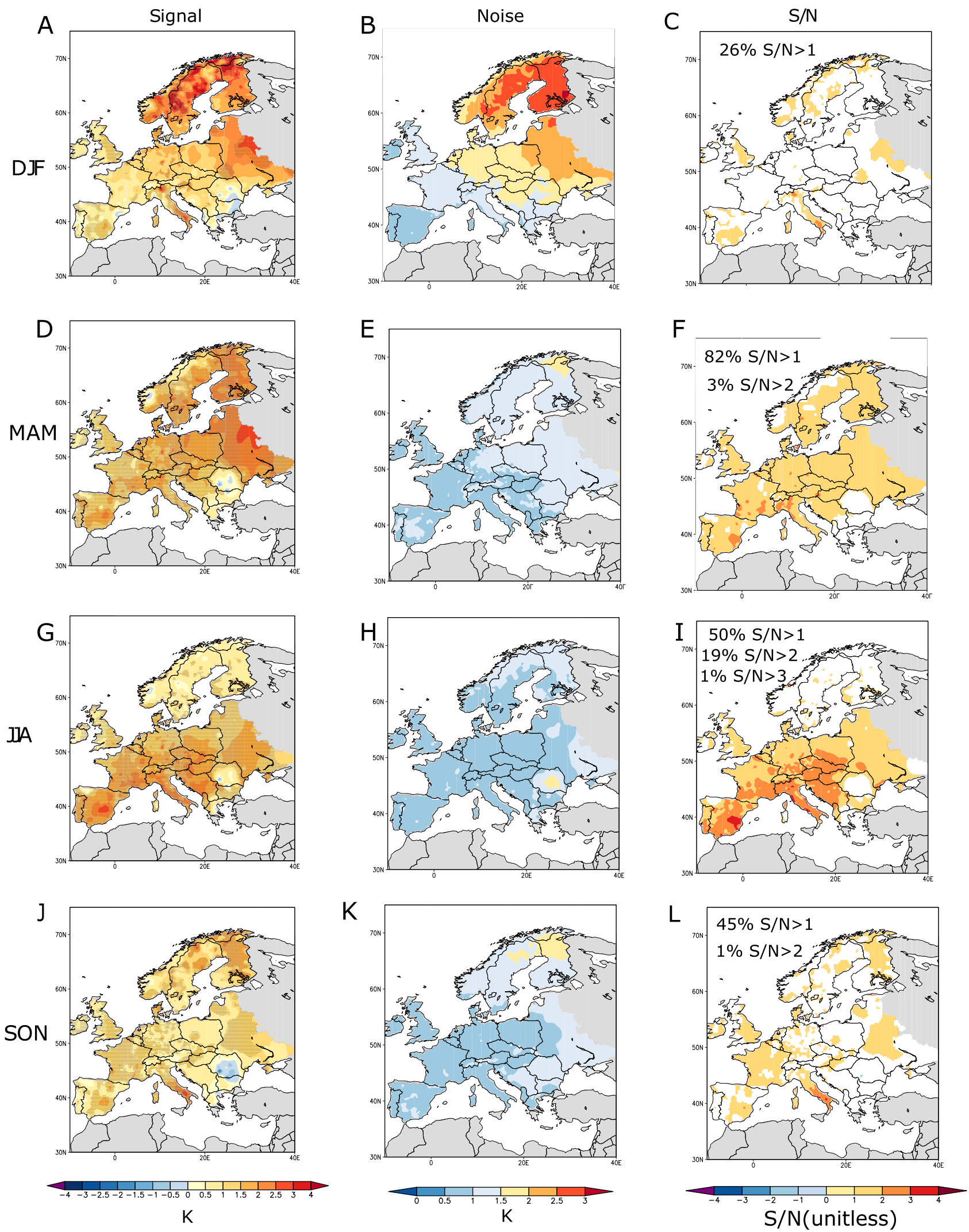
4Fig. 2 Signal (K), noise (K) and signal-to-noise (unitless) of seasonally averaged surface temperature anomalies (1951-2016) in the EOBS V17 dataset. Grey regions indicate a lack of sufficient data. Stippling in the signal plots (left column) indicates signal values statistically significantly different from zero. Only $\mathrm{S} / \mathrm{N}$ values statistically significantly from zero are shown (right column)

the $\mathrm{S} / \mathrm{N}$ of D32 is larger than 1 and 2 over $34 \%$ and $4 \%$ of Europe, respectively.

The indices analysed above show evidence of a general tendency towards warmer days and nights, which increase the probability of heat-related impacts. However, it is not only the peak temperatures but also the persistence of the heat waves which is relevant. To analyse changes in the persistence of hot events, we show in Fig. 3e the $\mathrm{S} / \mathrm{N}$ of the WSD index. The S/N of the WSD exhibits a NE tilted meridional dipole with values larger than 1 over southern Europe and below 1 over the rest of Europe. Overall, 19\% of Europe exhibits S/N ratios of WSD larger than 1.

\section{2 $\mathrm{S} / \mathrm{N}$ of precipitation-based indices}

\subsubsection{Seasonal total rainfall}

In winter, the spatial pattern of the Total Precipitation (TP) signal is characterised by a west-east tilted meridional dipole, with positive values over northern Europe, especially over western Scandinavia and Scotland and generally negative values in southern Europe, particularly over Spain and Portugal (Fig. 4a). An exception to this large-scale pattern is the Alpine region, which exhibits a significant positive signal as in northern Europe. In spring, the spatial pattern of the signal resembles that of winter, but the magnitudes of both positive and negative signals are smaller and generally not statistically significant (Fig. 4d). In summer, the spatial pattern is similar to winter and spring, but the magnitudes are about half the values in winter (Fig. 4g). Finally, in autumn, the signal does not show the distinctive west-east dipole pattern, and the magnitudes are small (Fig. $4 \mathrm{j}$ ). The noise pattern in winter, spring, and autumn shows higher values over the Atlantic facing areas of the continent and over the land area around the Gulf of Genova (Fig. 4b, e, k). This pattern is reminiscent of the first mode of variability of the Atlantic storm track (e.g., Rogers 1997; Pinto et al. 2009). In summer, the spatial pattern of the noise is more homogeneous (Fig. 4h). The $\mathrm{S} / \mathrm{N}$ in winter is larger than one and statistically significant only over some parts of Scandinavia, Scotland and the Baltic countries, covering about $13 \%$ of Europe. Simultaneously, a tiny area with $\mathrm{S} / \mathrm{N}$ smaller than -1 , denoting the emergence of unusually low precipitation totals, is observed over northwest
Italy in winter and spring (Fig. 4c, f). In summer and autumn, virtually all Europe ( $>99 \%$ ) exhibits a S/N smaller than one (Fig. 4i, 1).

\subsubsection{Flood-related indices}

Floods have different character depending on the geographical area, antecedent soil moisture, snowmelt, and the triggering meteorological situation (e.g., Whitfield 2012; Arheimer et al. 2017; Wasko and Sharma 2017). For example, on the Mediterranean coast and in Alpine regions, flooding often occurs in the form of flash floods, which are extreme events of short duration (typically a few hours) usually related to intense convective precipitation (Maddox et al. 1979; Marchi et al. 2010; Llasat et al. 2016). In Central Europe, floods are often related to persistent wet periods (e.g., Muchan et al. 2015; Pfleiderer et al. 2019) that saturate the soil and lead to overflow. In the first case, the precipitation intensity is the most relevant meteorological factor, while in the second is the compound effects of the total amount of precipitation, evapotranspiration and the duration of the wet period, which are more relevant (Berghuijs et al. 2019). Here we analyse hydroclimatic indices relevant for both types of events. In particular, we investigate the $\mathrm{S} / \mathrm{N}$ of the percentage of the total precipitation due to intense raining episodes (R95p) and the maximum 1-day precipitation (Rx1d), both related to the likelihood of flash floods (Acquaotta et al. 2019). Finally, we analysed the $\mathrm{S} / \mathrm{N}$ of the maximum 5-day consecutive precipitation ( $\mathrm{Rx} 5 \mathrm{~d}$ ) and the longest wet period (LWP), which are related to the likelihood of large flooding events.

In winter, the R95p signal is positive over most of Europe, although negative values are also observed over northern Italy and west Ukraine (Figure not shown). In the period 2000-2016, R95p amounts were about 5\% larger in central Europe and up to $20 \%$ larger in some areas of Scandinavia, Scotland and the eastern Alps compared with the 1951-1983 period. However, the magnitude of the R95p noise is comparable with that of the signal and therefore, the $\mathrm{S} / \mathrm{N}$ is generally below one except over Scandinavia and Scotland, where the $\mathrm{S} / \mathrm{N}$ is larger than 1 and above 2 in some locations (Fig. 5a). Overall, 15\% of Europe is experiencing unusually intense winter precipitation. In spring, summer and autumn, the signal, noise, and S/N's spatial pattern are similar to winter. However, the $\mathrm{S} / \mathrm{N}$ magnitudes are smaller than one virtually everywhere (not shown). In winter, the $\mathrm{S} / \mathrm{N}$ of $\mathrm{Rx} 1$ is larger than 1 and 2 over Scandinavia, the Baltic countries and Scotland (Fig. 5b). Overall, about $14 \%$ of Europe is experiencing unusually large amounts of winter daily accumulated precipitation. In spring, summer and autumn, Rx1d S/N values are all well below one (not shown). Finally, the winter S/N of RX5d is very similar to that of R95p. It is smaller than 1 over most of Europe except 
A

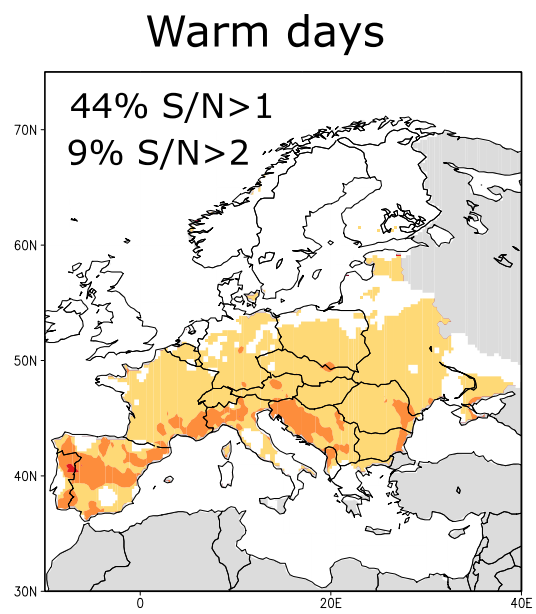

C

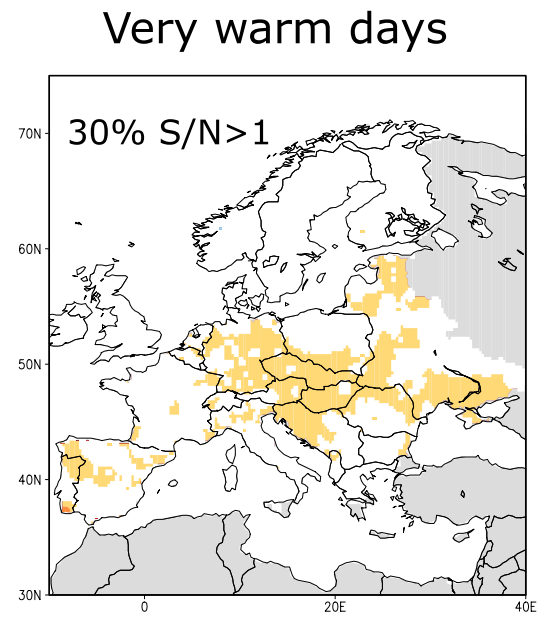

B

Warm nights

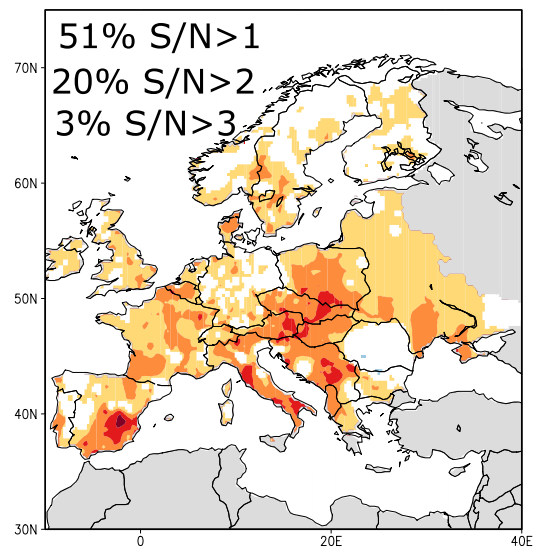

D Days with $\mathrm{T} x>32^{\circ} \mathrm{C}$

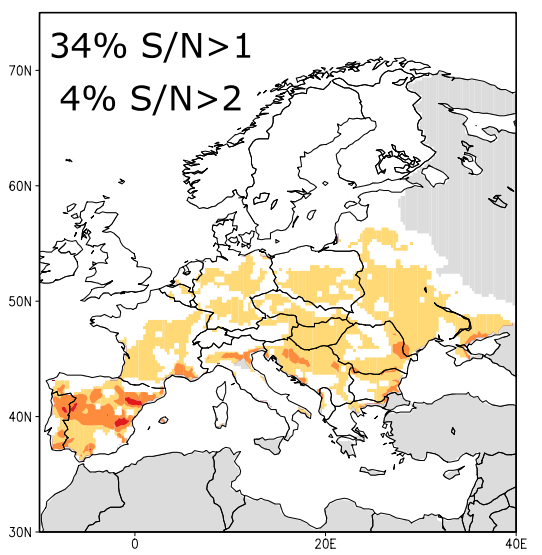

E Warm spell duration
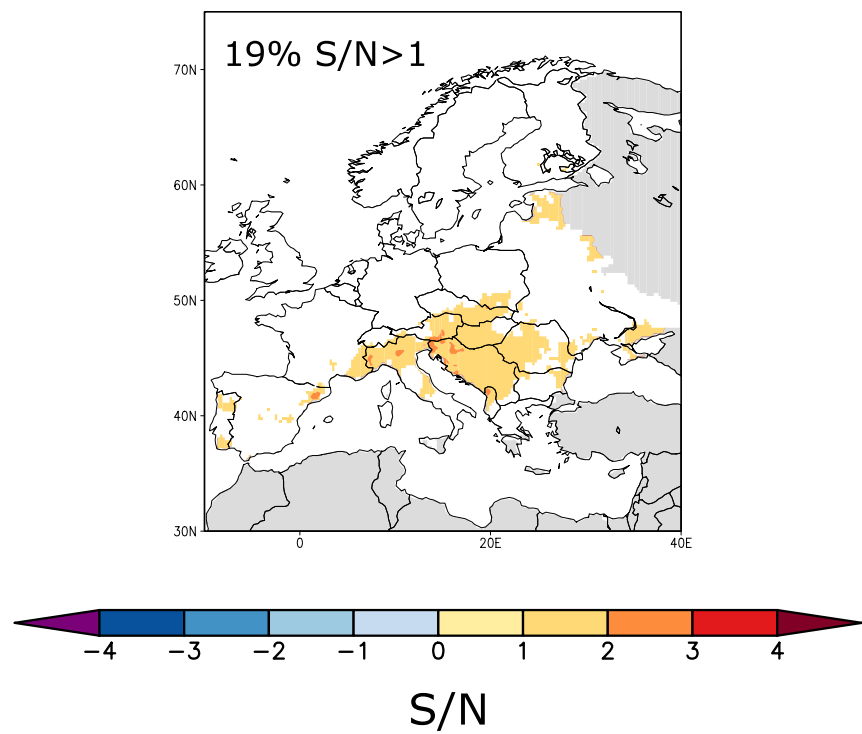
4Fig. 3 Signal-to-noise ratio (S/N) of summer (JJA) mean extreme temperature climate indices. Grey regions indicate a lack of sufficient data. Only values statistically significantly different from zero are shown

over some areas of Scandinavia, Scotland, north of Poland and the Baltic countries (Fig. 5c). In winter, 15\% of Europe currently experiences unusually large amounts of 5-days accumulated precipitation. As for the other two extreme precipitation indices, the $\mathrm{S} / \mathrm{N}$ values of RX5d are well below 1 for the other seasons (not shown).

Finally, we have also analysed the S/N of LWP (not shown). In all seasons, the $\mathrm{S} / \mathrm{N}$ is mostly smaller than 1 overall in Europe, suggesting that the persistence of the precipitation events has not changed significantly during the last decades.

\subsection{Drought-related indices}

The main drivers of hydrological droughts are lack of precipitation, soil moisture deficits and high evapotranspiration, the latter directly linked to high temperatures sustained over an extensive period (Seneviratne 2012). Here we analyse the $\mathrm{S} / \mathrm{N}$ of the standardised precipitation-evapotranspiration index calculated at a 3-month time scale (SPEI3). The SPEI3 index is widely used to characterise the changes in drought associated with climate change (Vicente-Serrano et al. 2010), and it can be interpreted as the number of standard deviations by which the observed anomaly deviates from the long-term mean. We also calculate the $\mathrm{S} / \mathrm{N}$ of the reference evapotranspiration index (ETO) and the standard precipitation index (SPI3) to help interpret the results. Finally, the $\mathrm{S} / \mathrm{N}$ of the Longest Dry Period (LDP) is also calculated. The SPEI3 and ETO indices are only available from 1979 to 2017 since the ETO is derived from the ERA5 reanalysis, which covers the period 1979-2020. Therefore, the baseline used for these three indices is 1980-1997 instead of 1951-1983 we used for the rest of the indices. It is also important to notice that ETO and SPEI3 require extra climate variables (besides temperature and precipitation) for their derivations. Therefore, the results should be interpreted with caution (see Methodology section). We show results only for summer since this is the only season with significant changes.

In summer, the S/N of SPEI3 depicts a distinct spatial pattern, with negative $\mathrm{S} / \mathrm{N}$ values (increased drought probability) over the Iberian Peninsula and eastern Europe $(\mathrm{S} / \mathrm{N}<-2)$ and positive values (reduced drought probability) in some parts of Scandinavia and Scotland $(\mathrm{S} / \mathrm{N}>1)$ (Fig. 6a). However, only a small fraction of values in the south of the Iberian Peninsula and eastern Europe are statistically significantly different from zero. Figure $6 c$ suggests that the summer drying in southern and southeastern Europe is dominated by a substantial increase in ETO, which shows $\mathrm{S} / \mathrm{N}$ values larger than 1 over most Continental Europe and larger than 2 and 3 over Spain and southeastern Europe. In contrast, the SPEI3 S/N increase over Scotland and Scandinavia appears to be driven by the positive changes in SPI3 (increased precipitation) over these areas. Overall, 27\%, $16 \%$, and $5 \%$ of Europe show $\mathrm{S} / \mathrm{N}$ values of ETO above 1 , 2 and 3. However, changes in drought probability relative to the 1951-1983 period have not yet emerged (not shown). Finally, the LDP S/N values are well under one everywhere in all seasons (figure not shown).

\section{Conclusions}

The S/N ratio of observed surface temperatures, precipitation and a set of impact-related climate indices associated with flooding, drought and extreme temperature have been investigated for the period 1951-2016 to evaluate how changes in climate metrics of direct relevance to society are emerging above the envelope of recent societal experience (1951-1983).

We have shown evidence that large parts of Europe are experiencing more severe climate extremes. Figure 7 illustrates schematically the most relevant summer and winter changes. Table 2 shows the percentage of European territory where the $\mathrm{S} / \mathrm{N}$ of different climate indices cross a certain threshold. The results indicate that summer episodes of extreme daily maximum temperatures have become more frequent over more than $55 \%$ of Europe. The changes in extreme (warm) night temperatures are even more extensive, with more than $74 \%$ of the European territory showing an emerging signal. $\mathrm{S} / \mathrm{N}$ values above 1 in D32 (days with maximum temperature above $32{ }^{\circ} \mathrm{C}$ ) are also observed over large parts of Continental Europe, and $\mathrm{S} / \mathrm{N}$ values above 2 are shown in the Iberian Peninsula. These results indicate that millions of people are currently experiencing unfamiliarly high temperatures, even compared to the recent past.

The flood-related climate indices analysis shows that the noise of precipitation and extreme precipitation time series is high, and over about $90 \%$ of Europe, the signal has not yet emerged in any season. However, some northern European areas, Scandinavia and Scotland, show the emergence of stronger winter precipitation events during winter.

Similarly to the flood-related indices, we found that the drought signal has only emerged over some reduced areas of southeastern Europe and the Iberia Peninsula driven by large 


\section{Total precipitation}
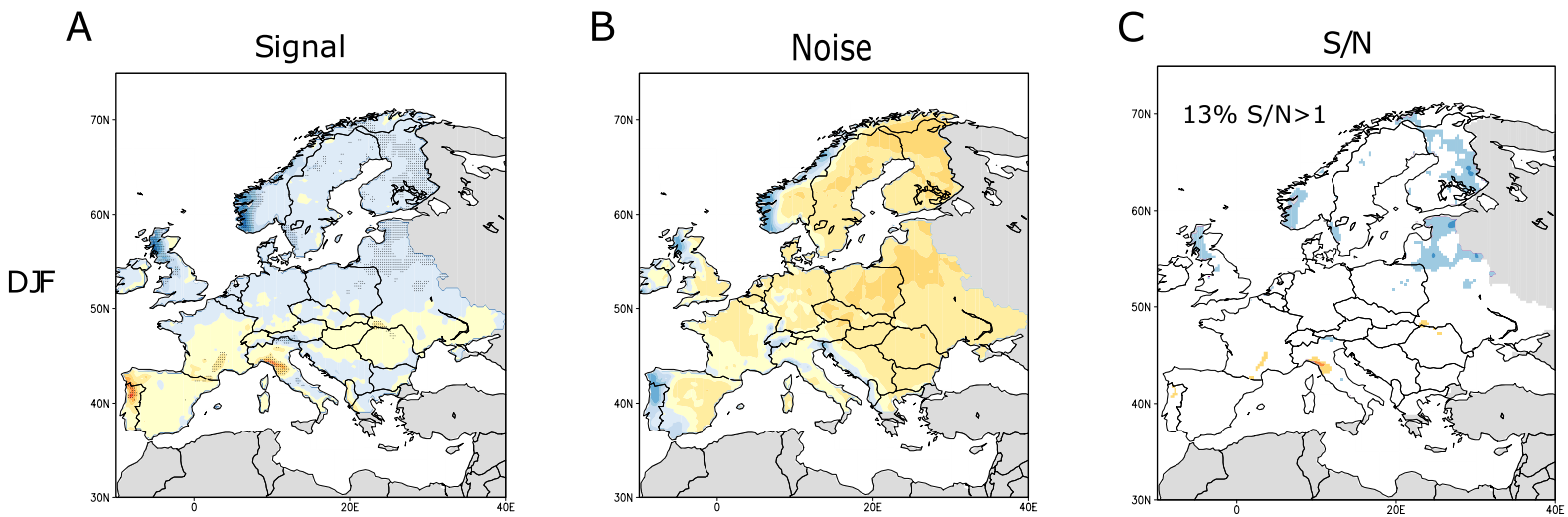

D

E
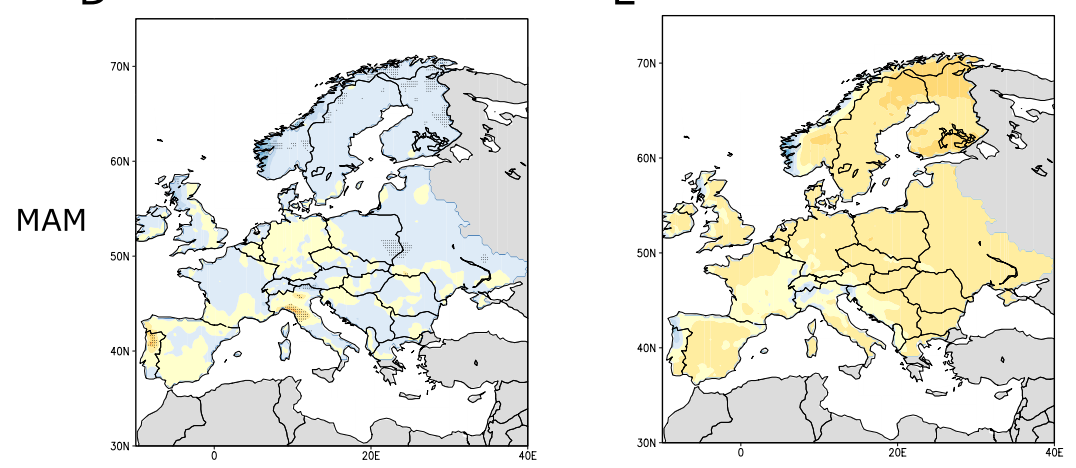

G

$\mathrm{H}$
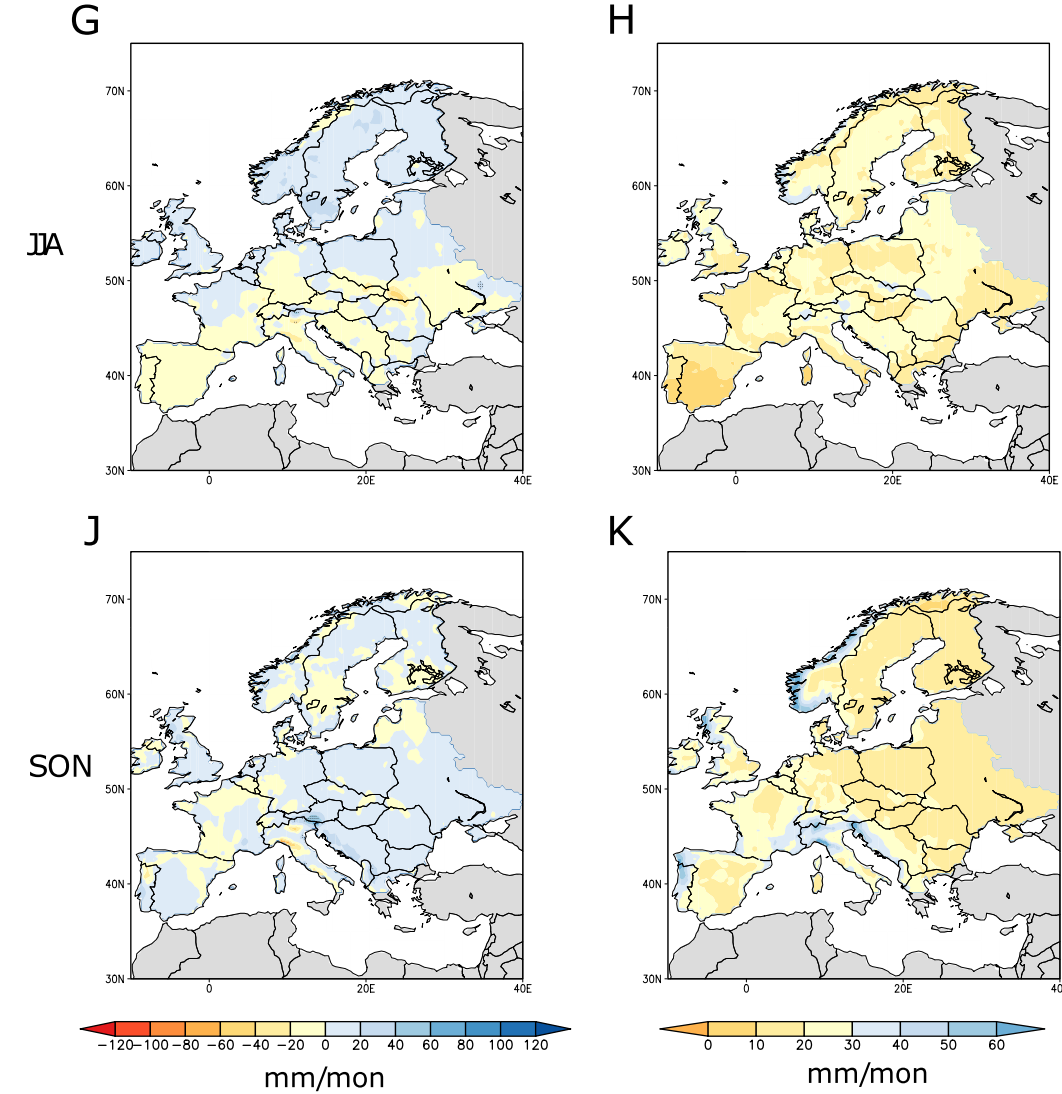

$\mathrm{F}$

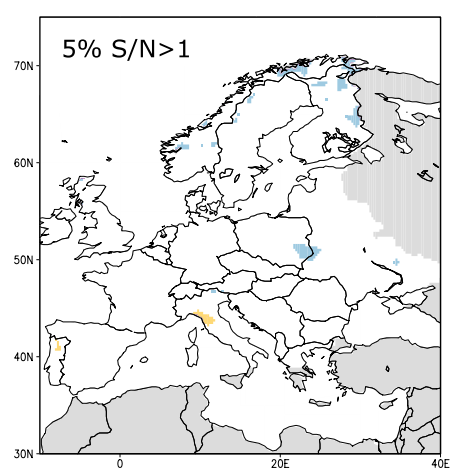

I

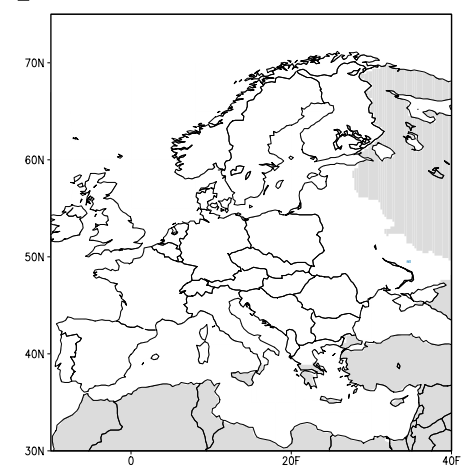

K

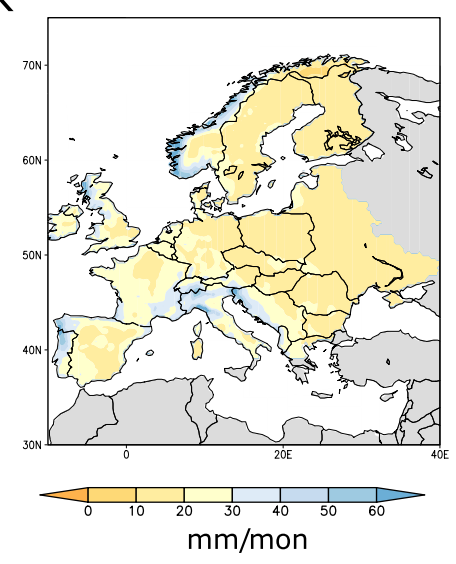

$\mathrm{L}$

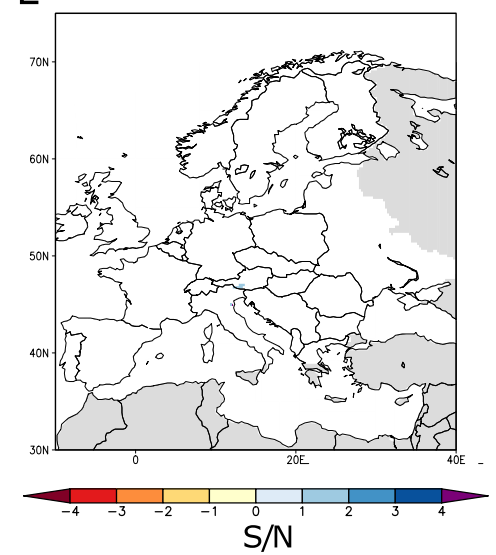

Fig. 4 As in Fig. 2 but for total precipitation anomalies 
Fig. 5 Signal-to-noise ratio $(\mathrm{S} / \mathrm{N})$ of winter extreme precipitation indices. Grey regions indicate a lack of sufficient data. Only values statistically significantly different from zero are shown
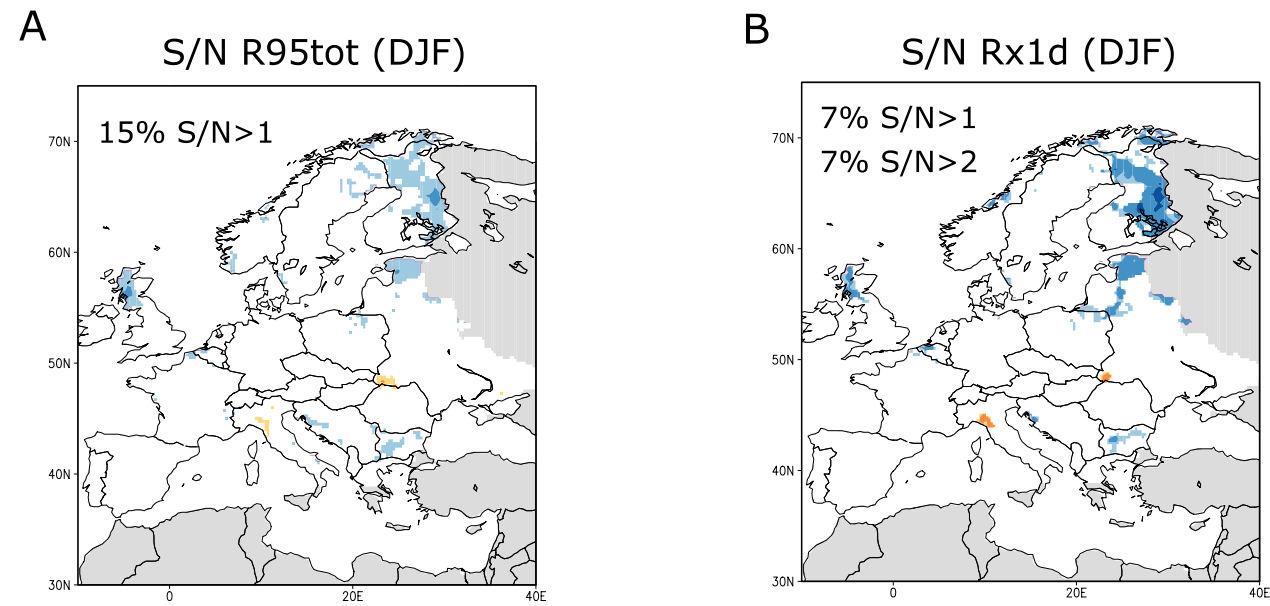

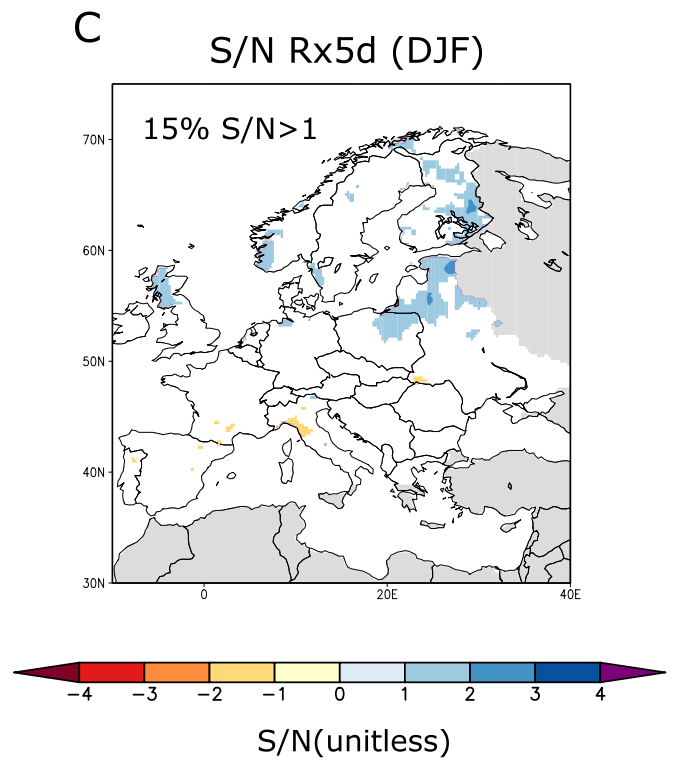

increases in the levels of potential evapotranspiration, which is much higher than in our baseline period (1951-1983) over most continental Europe.

Our analysis shows an earlier emergence and larger S/N ratios of temperature and precipitation extremes than found in other studies that used an earlier baseline period [e.g., King et al. (2015), Maraun (2013), Mahlstein et al. (2012), Zhang et al. (2007)]. It is important to note that 1950-1970 was a relatively cool period due to anthropogenic aerosol, and therefore the magnitude of the signals is potentially amplified when using our baseline period.

The analysis of the observed $\mathrm{S} / \mathrm{N}$ ratio of climate indicators with respect to a recent baseline provides useful and easily distillable information to many socio-economic sectors. The methodology used in this manuscript can be applied to more sector-specific indicators such as heat stress indicators, agricultural indicators (e.g., length of the growing season), snow days and snowmelt for ski tourism, 
Fig. 6 Signal-to-noise ratio $(\mathrm{S} / \mathrm{N})$ of summer droughtrelated indices. Grey regions indicate a lack of sufficient data. Stippling in figures (A, B) indicate values statistically significantly different from zero. In figure $(\mathbf{C})$, only values statistically significantly different from zero are shown

A

S/N SPEI3 (JJA)

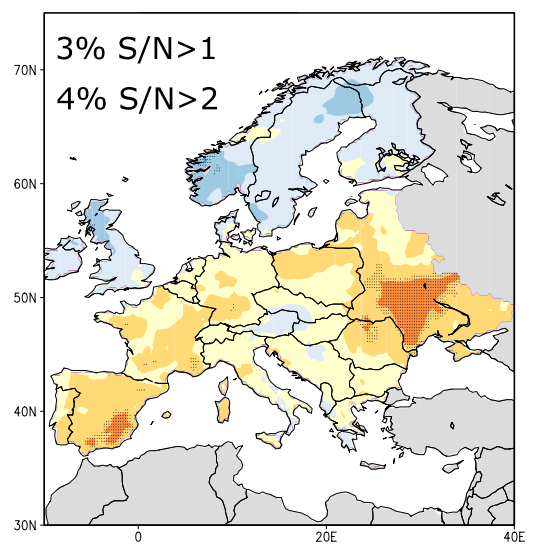

B S/N SPI3 (JJA)

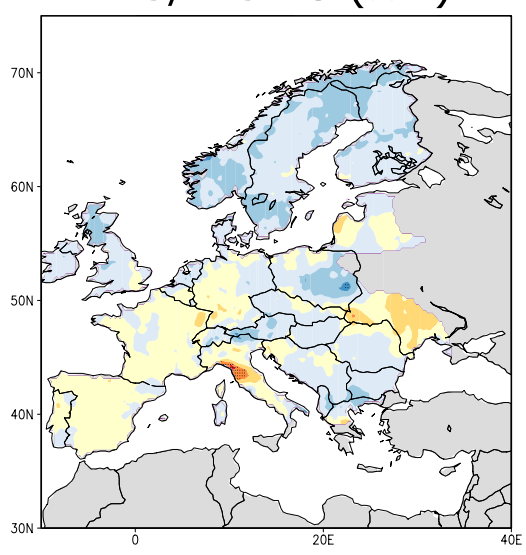

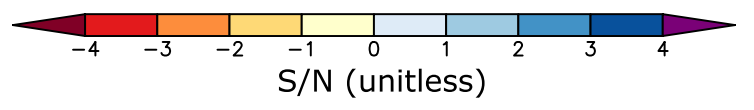

C

S/N ETO (JJA)

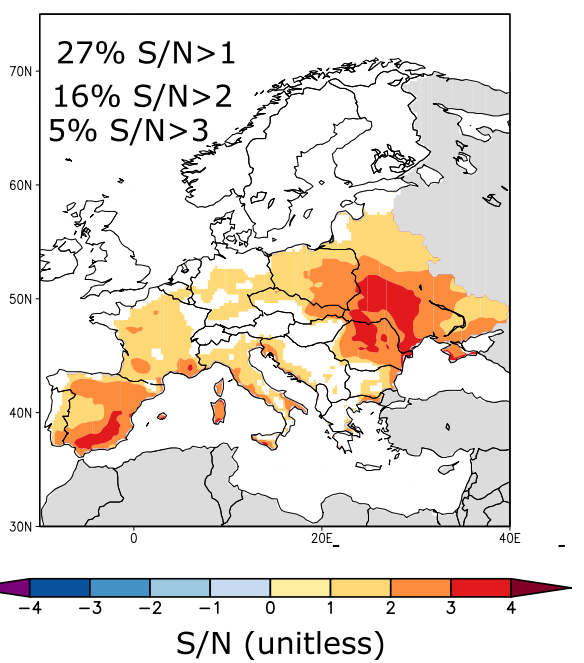


Fig. 7 Schematic showing the emergence of new climate extremes for winter $(\mathbf{A})$ and summer $(\mathbf{B})$ seasons
A

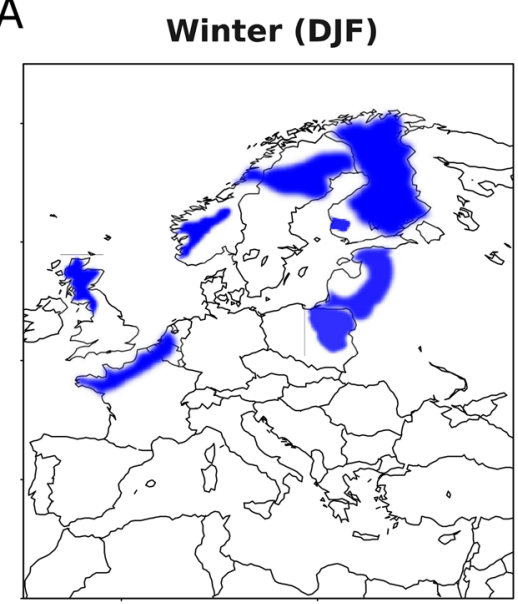

Emergence of stronger extreme precipitiation events
B

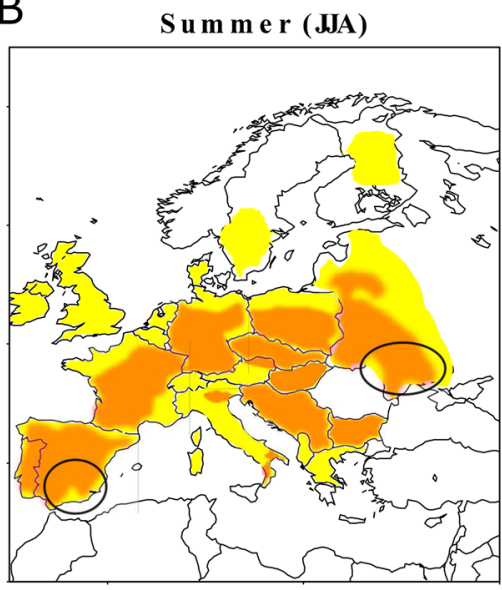

Increased number of days with extreme maximum temperatures

Increased number of night

with very high temperatures

Regions with enhanced drought-inducing conditions
Table 2 Percentage of the total European area with $\mathrm{S} / \mathrm{N}$ values of the indicated indices over a specific threshold (only statistically significant values are used to calculate the area)

\begin{tabular}{llll}
\hline & $1 \geq \mathrm{SN}<2$ & $2 \geq \mathrm{SN}<3$ & $3 \geq \mathrm{SN}<4$ \\
\hline $\begin{array}{llll}\text { INDICES DJF } \\
\text { Ts }\end{array}$ & $26 \%$ & $\sim 0 \%$ & $\sim 0 \%$ \\
RT & $13 \%$ & $0 \%$ & $\sim 0 \%$ \\
Rx1d & $7 \%$ & $7 \%$ & $\sim 0 \%$ \\
Rx5d & $15 \%$ & $0 \%$ & $\sim 0 \%$ \\
R95 & $15 \%$ & $0 \%$ & $\sim 0 \%$ \\
INDICES JJA & & & \\
Ts & $50 \%$ & $19 \%$ & $1 \%$ \\
WD & $44 \%$ & $9 \%$ & $\sim 0 \%$ \\
WN & $51 \%$ & $20 \%$ & $3 \%$ \\
VWD & $30 \%$ & $\sim 0 \%$ & $\sim 0 \%$ \\
D32 & $34 \%$ & $4 \%$ & $\sim 0 \%$ \\
WSD & $19 \%$ & $\sim 0 \%$ & $\sim 0 \%$ \\
SPEI3 & $3 \%$ & $4 \%$ & $\sim 0 \%$ \\
SPI3 & $\sim 0 \%$ & $\sim 0 \%$ & $\sim 0 \%$ \\
ETO & $27 \%$ & $16 \%$ & $5 \%$ \\
\hline
\end{tabular}

to enumerate a few. To achieve such aims, it is necessary to continue monitoring the European climate and these indices operationally.

Supplementary Information The online version contains supplementary material available at https://doi.org/10.1007/s00382-021-05917-3.

Acknowledgements This work was funded by the INDECIS project which is part of ERA4CS, an ERA-NET initiated by JPI Climate, and funded by FORMAS (SE), DLR (DE), BMWFW (AT), IFD (DK),
MINECO (ES), ANR (FR) with co-funding by the European Union Grant 690462).

Funding Open access funding provided by University of Graz.

Open Access This article is licensed under a Creative Commons Attribution 4.0 International License, which permits use, sharing, adaptation, distribution and reproduction in any medium or format, as long as you give appropriate credit to the original author(s) and the source, provide a link to the Creative Commons licence, and indicate if changes were made. The images or other third party material in this article are included in the article's Creative Commons licence, unless indicated otherwise in a credit line to the material. If material is not included in the article's Creative Commons licence and your intended use is not permitted by statutory regulation or exceeds the permitted use, you will need to obtain permission directly from the copyright holder. To view a copy of this licence, visit http://creativecommons.org/licenses/by/4.0/.

\section{References}

Acquaotta F, Faccini F, Fratianni S et al (2019) Increased flash flooding in Genoa Metropolitan Area: a combination of climate changes and soil consumption? Meteorol Atmos Phys 131:1099-1110. https://doi.org/10.1007/s00703-018-0623-4

Arheimer B, Donnelly C, Lindström G (2017) Regulation of snow-fed rivers affects flow regimes more than climate change. Nat Commun 8:62. https://doi.org/10.1038/s41467-017-00092-8

Beaumont LJ, Pitman A, Perkins S, Zimmermann NE, Yoccoz NG, Thuiller W (2011) Impacts of climate change on the worlds most exceptional ecoregions. Proc Natl Acad Sci 108(6):2306-2311. https://doi.org/10.1073/pnas.1007217108

Berghuijs WR, Harrigan S, Molnar P, Slater LJ, Kirchner JW (2019) The relative importance of different flood-generating mechanisms across Europe. Water Resour Res 55:4582-4593. https://doi.org/ 10.1029/2019WR024841 
Chiew FHS, Kamaladasa NN, Malano HM, McMahon TA (1995) Penman-Monteith, FAO-24 reference crop evapotranspiration and class-A pan data in Australia. Agric Water Manage 28:9-21

Christensen JH et al (2007) Regional climate projections. In: Solomon S et al (eds) Climate change 2007: the physical science basis. Cambridge Univ. Press, Cambridge, pp 847-940

Cornes R, van der Schrier G, van den Besselaar EJM, Jones PD (2018) An ensemble version of the E-OBS temperature and precipitation datasets. J Geophys Res Atmos. https://doi.org/10.1029/2017J D028200

Cowtan K, Way RG (2014) Coverage bias in the HadCRUT4 temperature series and its impact on recent temperature trends. Q J R Meteorol Soc 140:1935-1944. https://doi.org/10.1002/qj.2297

Dai A, Trenberth KE, Karl TR (1999) Effects of clouds, soil moisture, precipitation, and water vapor on diurnal temperature range. J Clim 12:2451-2473. https://doi.org/10.1175/1520-0442(1999) 012\%3c2451:EOCSMP\%3e2.0.CO;2

Dessens J, Bücher A (1995) Changes in minimum and maximum temperatures at the Pic du Midi in relation with humidity and cloudiness. Atmos Res 37:147-162. https://doi.org/10.1016/01698095(94)00075-O

Deutsch CA, Tewksbury JJ, Huey RB, Sheldon KS, Ghalambor CK, Haak DC, Martin PR (2008) Impacts of climate warming on terrestrial ectotherms across latitude. Proc Natl Acad Sci 105(18):6668-6672. https://doi.org/10.1073/pnas.0709472105

Dillon M, Wang G, Huey R (2010) Global metabolic impacts of recent climate warming. Nature 467:704-706. https://doi.org/10.1038/ nature09407

Domínguez-Castro F, Reig F, Vicente-Serrano SM et al (2020) A multidecadal assessment of climate indices over Europe. Sci Data 7:125. https://doi.org/10.1038/s41597-020-0464-0

Fischer EM, Knutti R (2014) Detection of spatially aggregated changes in temperature and precipitation extremes. Geophys Res Lett 41:547-554. https://doi.org/10.1002/2013GL058499

Frame D, Joshi M, Hawkins E et al (2017) Population-based emergence of unfamiliar climates. Nat Clim Change 7:407-411. https://doi. org/10.1038/nclimate3297

Giorgi F, Bi X (2009) Time of emergence (TOE) of GHG-forced precipitation change hot-spots. Geophys Res Lett 36:L06709. https:// doi.org/10.1029/2009GL037593

Harrington LJ, Frame DJ, Fischer EM, Hawkins E, Joshi M, Jones CD (2016) Poorest countries experience earlier anthropogenic emergence of daily temperature extremes. Environ Res Lett 11(5):055007

Hawkins E, Sutton R (2012) Time of emergence of climate signals. Geophys Res Lett 39:L01702. https://doi.org/10.1029/2011G L050087

Hawkins E, Frame D, Harrington L, Joshi M, King A, Rojas M, Sutton R (2020) Observed emergence of the climate change signal: From the familiar to the unknown. Geophys Res Lett 47:e2019GL086259. https://doi.org/10.1029/2019GL086259

Henderson-Sellers A (1992) Continental cloudiness changes this century. GeoJournal 27:255-262. https://doi.org/10.1007/ BF02482666

Kaas E, Frich P (1995) Diurnal temperature range and cloud cover in the Nordic countries: observed trends and estimates for the future. Atmos Res 37:211-228. https://doi.org/10.1016/01698095(94)00078-R

King AD et al (2015) The timing of anthropogenic emergence in simulated climate extremes. Environ Res Lett 10:094015. https:// doi.org/10.1088/1748-9326/10/9/094015

Klein Tank AMG, Zwiers FW, Zhang X (2009) Guidelines on analysis of extremes in a changing climate in support of informed decisions for adaptation, climate data and monitoring WCDMP-No. 72, WMO-TD No. 1500, p 5
Llasat MC, Marcos R, Turco M, Gilabert J, Llasat-Botija M (2016) Trends in flash flood events versus convective precipitation in the Mediterranean region: the case of Catalonia. J Hydrol 541:24-37. https://doi.org/10.1016/j.jhydrol.2016.05.040

Maddox RA, Chappell CF, Hoxit LR (1979) Synoptic and Meso- $\alpha$ scale aspects of flash flood events. Bull Am Meteorol Soc 60:115-123. https://doi.org/10.1175/1520-0477-60.2.115

Mahlstein I, Knutti R, Solomon S, Portmann RW (2011) Early onset of significant local warming in low latitude countries. Environ Res Lett 6(3):034009

Mahlstein I, Hegerl G, Solomon S (2012) Emerging local warming signals in observational data. Geophys Res Lett. https://doi.org/ $10.1029 / 2012$ GL053952

Maraun D (2013) When will trends in European mean and heavy daily precipitation emerge? Environ Res Lett 8:14004. https:// doi.org/10.1088/1748-9326/8/1/014004

Marchi L et al (2010) Characterisation of selected extreme flash floods in Europe and implications for flood risk management. J Hydrol 394:118-133. https://doi.org/10.1016/j.jhydrol.2010. 07.017

McCabe GJ, Legates DR, Lins HF (2010) Variability and trends in dry day frequency and dry event length in the southwestern United States. J Geophys Res 115:D07108. https://doi.org/10.1029/2009J D012866

McKee TB, Doesken NJ, Kleist J (1993) The relationship of drought frequency and duration to time scales. In: Proceedings of the eighth conference on applied climatology, American Meteorological Society, pp 179-184

Meehl GA, Tebaldi C (2004) More intense, more frequent, and longer lasting heat waves in the 21st century. Science 305(5686):994997. https://doi.org/10.1126/science.1098704

Muchan K, Lewis M, Hannaford J, Parry S (2015) The winter storms of 2013/2014 in the UK: hydrological responses and impacts. Weather 70:55-61. https://doi.org/10.1002/wea.2469

Perkins SE, Alexander LV, Nairn JR (2012) Increasing frequency, intensity and duration of observed global heatwaves and warm spells. Geophys Res Lett. https://doi.org/10.1029/2012GL053361

Pfleiderer P, Schleussner CF, Kornhuber K, Coumou D (2019) Summer weather becomes more persistent in a $2{ }^{\circ} \mathrm{C}$ world. Nat Clim Change 9(9):666-671. https://doi.org/10.1038/s41558-019-0555-0

Pinto JG, Zacharias S, Fink AH et al (2009) Factors contributing to the development of extreme North Atlantic cyclones and their relationship with the NAO. Clim Dyn 32:711-737. https://doi. org/10.1007/s00382-008-0396-4

Robine JM et al (2008) Death toll exceeded 70,000 in Europe during the summer of 2003. C R Biol 331:171-178. https://doi.org/10. 1016/j.crvi.2007.12.001

Rogers JC (1997) North Atlantic storm track variability and its association to the North Atlantic Oscillation and climate variability of Northern Europe. J Clim 10:1635-1647. https://doi.org/10.1175/ 1520-0442(1997)010\%3c1635:NASTVA\%3e2.0.CO;2

Seneviratne S (2012) Historical drought trends revisited. Nature 491:338-339. https://doi.org/10.1038/491338a

Sutton RT, Dong B, Gregory JM (2007) Land/sea warming ratio in response to climate change: IPCC AR4 model results and comparison with observations. Geophys Res Lett 34:L02701. https:// doi.org/10.1029/2006GL028164

Sutton R, Suckling E, Hawkins E (2015) What does global mean temperature tell us about local climate? Philos Trans R Soc A Math Phys Eng Sci 373(2054):20140426. https://doi.org/10.1098/rsta. 2014.0426

Trenberth KE, Fasullo JT (2012) Climate extremes and climate change: the Russian heat wave and other climate extremes of 2010. J Geophys Res 117:D17103. https://doi.org/10.1029/2012JD018020

Trigo RM, García-Herrera R, Díaz J, Trigo IF, Valente MA (2005) How exceptional was the early August 2003 heatwave in France? 
Geophys Res Lett 32:L10701. https://doi.org/10.1029/2005G L022410

Vicente-Serrano SM, Beguería S, López-Moreno JI (2010) A multiscalar drought index sensitive to global warming: the standardized precipitation evapotranspiration index. J Clim 23(7):1696-1718. https://doi.org/10.1175/2009JCLI2909.1

Wasko C, Sharma A (2017) Global assessment of flood and storm extremes with increased temperatures. Sci Rep 7:7945. https:// doi.org/10.1038/s41598-017-08481-1

Whitfield P (2012) Changing floods in future climates. J Flood Risk Manag 5:336-365. https://doi.org/10.1111/j.1753-318X.2012. 01150.x
Wilks DS (2006) Statistical methods in the atmospheric sciences. vol 91. Academic Press, Elsevier, San Diego, CA, USA, p 627

Zhang X, Zwiers F, Hegerl G et al (2007) Detection of human influence on twentieth-century precipitation trends. Nature 448:461-465. https://doi.org/10.1038/nature06025

Publisher's Note Springer Nature remains neutral with regard to jurisdictional claims in published maps and institutional affiliations. 